\section{Contributors}

A Gordon Baird

gordon.baird@nhs.net

www.rcgp.org.uk/ruralforum

www.ruralgp.org.uk

Hugh Barr

barrh@westminster.ac.uk

Mike Fitzpatrick

fitz@easynet.co.uk

John Frey

John.Frey@FAMMED.WISC.EDU

David Hogg

www.rcgp.org.uk/ruralforum

www.ruralgp.org.uk

Hugh Ip

hughip@gmail.com

Roger Jones

rjones@rcgp.org.uk

\section{Frank Minns}

frank@c21gardens.com

Lesley Morrison

Lesley.Morrison@borders.scot.nhs.uk

James Willis

jarwillis@googlemail.com

http://www.friendsinlowplaces.co.uk

\title{
Keep on taking the courses
}

For years my wife has had the privilege of belonging to an adult education class taken by one of the foremost glassengravers in the country. The latter fits this into an incredibly demanding life imagine weeks of arduous and intricate work on a glass panel being occasionally and unpredictably destroyed in the toughening process - purely out of love and affection for her devoted pupils. And in spite of the manifest quality of her sensitive, inspiring, and individuallytailored teaching, this consummate craftsman has to jump through a host of bureaucratic hoops in order to continue the class. For example it has recently been decreed that she must produce advance plans, wonderfully fashionable but utterly inappropriate for her proven teaching style, for every session. And now she is also sent on 'trainings' - recent ones include first aid, child protection (none of her pupils are much younger than my wife is) - and now, of all things, e-learning which has as much relevance to glass engraving as Indian smoke signals. All of this is compulsory and has to take priority over the requirements of even the most august and impatient clients.

One of my daughters is in housing management. I couldn't list in my available space all the 'trainings' she is expected to arrange for her staff, so she has chosen me an example: asbestos. This 2-hour session was recently declared mandatory for anyone on the 'front-line', that is anyone who visits properties. Thus 15 busy people were expected to drop everything at 10-days notice, in spite of the fact that only two of them had any dealings with properties which actually contained asbestos (there is a database). What actually happened was that one person went and then spent 10 minutes passing on the essential message to the others at the next team meeting. The burden of this was that they should keep an eye open for damage and report any concerns to one of the maintenance surveyors whose job it was to know what to do next.

My other daughter manages a laboratory which delivers an essential public service. She too tells us of being required to send her staff on constant, disruptive courses - recently the whole complement have been through compulsory risk assessment training, ladder training, and 2 days of (tautologically enough) manual handling. She has made the bold suggestion that these related areas might perhaps be combined. But as she herself climbs the ladder she does see the bureaucrats' point of view - she says you simply have to be seen to be doing all the 'right things' otherwise in the current climate if things go wrong you really do feel you might find yourself in prison.

Of course nothing like this happens in general practice, GPs are too sensible and powerful to allow it. If it did they would just have to ask for the evidence base for such a vast expenditure of time and money yielding any (let alone commensurate) benefits, and if that failed they would tell the people seeking to usurp their professionalism to justify themselves by telling them exactly what to stop doing instead.

Nonetheless, as the above stories are the experience of every member of my immediate family, I suspect quite a few GPs will recognise what I am talking about too, and that some of them will share my concern about the damage this escalating phenomenon is doing to our society. As one of the few professional generalists left, they are well placed to recognise how intractable the problem is for an officialdom which sees exclusively with the narrowly focused view. From this stance it is impossible to argue against any one of these 'initiatives' without sounding irresponsible. But from the broader perspective, the one which has served mankind from the dawn of civilisation until the last few years: in the context of the great 'everything else' of life, they emerge as simple lunacy.

DOI: 10.3399/bjgp10X484101 